1. References [Rodríguez-García et al. 2010, Pausas and Keeley 2014, Rodríguez-García et al. 2010] are cited in text but not provided in the reference list. Please provide references in the list or delete these citations.

\title{
Germination response of woody species to laboratory-simulated fire severity and airborne nitrogen deposition: a post-fire recovery strategy perspective
}

Luz Valbuena, $1 \square$

Phone 0034987293405

Email luz.valbuena@unileon.es

Angela Taboada, 1

Reyes Tárrega, 1

Ainhoa De la Rosa, 1

Leonor Calvo, 1

1 Area of Ecology, Department of Biodiversity and Environmental Management, University of León, Campus Vegazana s/n, 24071 León, Spain

Received: 1 March 2019 / Accepted: 18 September 2019

\begin{abstract}
Two drivers of global change that affect ecosystem function include wildland fire regimes characterised by frequent, severe fires and increased atmospheric nitrogen $(\mathrm{N})$ deposition. However, their combined effect on the post-fire recovery of Mediterranean forests is still little known. We assessed the interactive effects of two fire severities and $\mathrm{N}$ addition on the rate and timing of seed germination of three woody species with different post-fire regeneration strategies in fire-prone forests: Pinus pinaster, an obligate-seeder species, and two facultative-seeder species, Pterospartum tridentatum (high-resprouting and low-seeding ability) and Halimium lasianthum (low-resprouting and high-seeding ability). Seeds were subjected to six combinations of temperature [control (no heat treatment), $60{ }^{\circ} \mathrm{C}$ (moderate fire severity) and $120{ }^{\circ} \mathrm{C}$ (high fire
\end{abstract}


severity) for $5 \mathrm{~min}$ ] and $\mathrm{N}$ fertilisation (without $\mathrm{N}$ and with addition of $4.17 \mathrm{~g} \mathrm{Nm}^{-2}$ of solid granules of ammonium nitrate, equivalent to three times the current estimate of airborne $\mathrm{N}$ deposition in the study area) under laboratory conditions. We found that $\mathrm{N}$ fertilisation had a significant, negative effect on the rate of seed germination of the three species under study. Additionally, we detected no differences in $P$. pinaster germination among thermal treatments; while both $P$. tridentatum and $H$. lasianthum had significantly higher germination rates when submitted to high fire-severity conditions. Moreover, the average time of seed germination increased with $\mathrm{N}$ fertilisation for $P$. pinaster but increased after the thermal treatments for $H$. lasianthum. These results suggest that increased $\mathrm{N}$ availability under intense wildfire regimes may hinder post-fire seed germination, regardless of the species' regeneration strategy, in fire-prone pine forests.

\section{Keywords}

Atmospheric nitrogen deposition

Germination

Halimium lasianthum

Pinus pinaster

Pterospartum tridentatum

Communicated by Devan Allen McGranahan.

\section{Introduction}

Recurring disturbances such as wildfires affect the dynamics of many ecosystems worldwide (Turner 2010) and exert a strong evolutionary pressure on plants. As a consequence, numerous species have acquired adaptive traits and mechanisms that confer fitness benefits in repeatedly disturbed environments such as Mediterranean fire-prone ecosystems (Pausas and Keeley 2014). In these ecosystems, the post-fire regeneration of plant species largely depends on their ability to withstand high temperatures during fire (Paula and Pausas 2008) and tolerate repeated burning (e.g. De las Heras et al. 2012), as well as on their strategy for persisting after fire (i.e. essentially, germinating or resprouting; Paula and Pausas 2008; Pausas and Keeley 2014). Indeed, many woody species in these fire-prone environments have heat-tolerant or heat-stimulated germination (e.g. species with physical dormancy; Moreira et al. 2010) that require either a persistent soil/aerial seed bank or the production of heat-resistant seeds (Paula and Pausas 2008; Rivas 2016; Trabaud and Oustric 1989). However, in recent decades, extreme fire events have compromised the natural recovery and the resilience of fire-prone ecosystems across the Mediterranean basin (Doblas-Miranda et al. 2017; San-Miguel-Ayanz et al. 2013 and references therein), with future projections of increased fire extent, frequency, severity and seasonal duration due to climate change and land use transformation (Moreira et al. 2011; Pausas and Paula 2012; Pausas et al. 2008). Under these novel conditions, there might be both a decrease in the resprouting ability of plants and a failure of seeders recruitment, thus altering plant species composition and dominance (e.g. González-De Vega et al. 2016; Moya et al. 2015; Taboada et al. 2017).

To date, many experiments have submitted seeds of Mediterranean woody species to different thermal shock treatments and have confirmed the key role of heat intensity in post-fire germination (see review by Paula and Pausas 2008). Nonetheless, many factors beyond fire temperature influence both the loss of seed dormancy and the rate of post-fire recruitment (e.g. light and daily temperature fluctuations, Baskin and Baskin 2001; smoke, Keeley and Pausas 2018; Moreira and Pausas 2018; Moreira et al. 2010). Indeed, changes in soil nutrient concentrations following fire 
affect seed germination and seedling recruitment (e.g. Calvo et al. 2008), especially in fire-prone ecosystems (Mayor et al. 2016). In particular, enhanced soil nitrogen (N) availability after fire (Henig-Sever et al. 2000; Marcos et al. 2009; Serrasolses and Vallejo 1999) could help breaking seed dormancy and promoting post-fire germination (Thanos and Rundel 1995). But there is no consistent evidence for a positive effect of the released soil $\mathrm{N}$ compounds on seed germination after fire, as this effect might be life form-specific, species-dependent or even inhibitory (Bell et al. 1999; Luna and Moreno 2009; Pérez-Fernández and Rodríguez-Echeverría 2003).

AQ1

Moreover, post-fire soil $\mathrm{N}$ availability in Mediterranean environments is very likely influenced by the elevated rates of atmospheric $\mathrm{N}$ deposition in this area due to pollution (García-Gómez et al. 2014; Ochoa-Hueso et al. 2011). These anthropogenic $\mathrm{N}$ inputs are currently one of the main threats to Mediterranean ecosystems, leading to the loss of biodiversity and to changes in structure and ecological function (Bobbink et al. 2010; Calvo-Fernández et al. 2018; Jones et al. 2014; OchoaHueso et al. 2013, 2014). Several long-term experiments have demonstrated the interactive effects of wildfires and $\mathrm{N}$ addition on soil chemistry and microbiology (e.g. Green et al. 2013; Southon et al. 2012), and on plant species richness and community composition (e.g. Britton and Fisher 2007; Southon et al. 2012). Yet, to our knowledge, no studies have assessed the response of post-fire seed germination and seedling recruitment to increased airborne $\mathrm{N}$ deposition in Mediterranean fire-prone environments. Furthermore, how the combination of novel wildfire regimes with even more frequent high-severity fires and enhanced soil $\mathrm{N}$ availability might affect the regeneration of Mediterranean ecosystems remains undetermined. It is therefore essential to investigate how the soil temperatures attained during a fire and the rate of $\mathrm{N}$ loading jointly influence the post-fire germination of coexisting species typical of Mediterranean fire-prone ecosystems with different regeneration strategies. This information will aid understanding plant competitive interactions at early successional stages after fire and support effective post-fire management.

The aim of this study was to analyse the joint effect of fire severity and increased atmospheric $\mathrm{N}$ deposition on the germination response of three typical woody species (one tree and two shrubs), with different post-fire regeneration strategies, from a Mediterranean fire-prone forest ecosystem, i.e. Pinus pinaster Ait., an obligate-seeder species (Tapias et al. 2001, 2004), and two facultativeseeder species, Pterospartum tridentatum (L.) Willk. (high-resprouting and low-seeding ability; Reyes et al. 2009) and Halimium lasianthum subsp. alyssoides (Lam.) Greuter (low-resprouting and high-seeding ability; Rivas 2016). To achieve this aim, we experimentally simulated under laboratory conditions (1) the temperatures experienced during a wildfire by submitting the seeds of the three species to three thermal treatments (control, moderate- and high-severity wildfire) for the same exposure time; and (2) the current estimates of airborne $\mathrm{N}$ deposition in the study area by the addition of solid granules of ammonium nitrate to the seed germination dishes. Following Keeley (2009) and Key and Benson (2006), we use the term 'fire severity' to indicate the magnitude of environmental change caused by fire that is positively correlated with fire intensity (i.e. the energy output from fire) and, thus, with the soil temperatures attained during fire. As such, this approach represents a continuation of a previous study from our research group (Calvo et al. 2016) in which we demonstrated that seed provenance and weight influence both the rate and timing of germination and the early seedling growth of $P$. pinaster. In particular, highly-serotinous $P$. pinaster populations adapted to frequent fires have comparably lighter seeds with lower heat tolerance (lower germination rates, higher germination times and lower seedling lengths) than very low serotinous populations. Although our previous findings will help restoration aimed at forest regrowth in fireprone pine areas, we still know very little about how post-fire natural tree regeneration will cope with increased $\mathrm{N}$ loading, which needs further research. 
Based on prior studies, we expect to find: (i) no significant differences in P. pinaster germination among the thermal treatments (Calvo et al. 2016; Martínez-Sánchez et al. 1995; Reyes and Casal 2008; Torres et al. 2006), i.e. heat tolerance sensu Paula and Pausas (2008); (ii) enhanced germination of $P$. tridentatum seeds under both low and high fire-severity treatments (Rivas et al. 2006; Valbuena et al. 2002), i.e. heat-stimulated germination sensu Paula and Pausas (2008) and (iii) an increase in the germination of $H$. lasianthum seeds only under the high fire-severity treatment (Herranz et al. 1999; Núñez et al. 2003; Trabaud and Oustric 1989; Valbuena et al. 1992), i.e. heatstimulated germination. Furthermore, we expect either no effect or a negative effect of high $\mathrm{N}$ addition on the post-fire germination of the three woody species studied under the low fire-severity treatment (Bell et al. 1999; Pérez-Fernández and Rodríguez-Echeverría 2003). Additionally, we explore the interactive effects of high fire-severity and $\mathrm{N}$ addition on seed germination due to the potential complex effects of high fire-attained temperatures on soil chemistry and enzymatic activities in fire-prone pine ecosystems (Fernández-García et al. 2019a, b).

\section{Materials and methods}

\section{Seed material}

Seeds were collected at Sierra del Teleno mountain range (NW Spain; $42^{\circ} 15^{\prime} 34^{\prime \prime} \mathrm{N} / 06^{\circ} 12^{\prime} 13^{\prime \prime} \mathrm{W}$; 850-2100 $\mathrm{m}$ a.s.1.; $10 \%$ average slope), a landscape dominated by maritime pine (P. pinaster) natural forests with a tall (up to $1.5 \mathrm{~m}$ height) shrubby understorey with Erica australis L., $P$. tridentatum and $H$. lasianthum. The climate is Mediterranean with an average annual rainfall between 650 and $900 \mathrm{~mm}$, mean annual temperature of $10^{\circ} \mathrm{C}$ and $2-3$ months of summer drought. Soils are Cambisols, very sandy and acidic $(\mathrm{pH} 4.66 \pm 0.25)$ with low organic matter content (LuisCalabuig et al. 2002). Wildfires are very frequent, typically caused by dry lightning storms [172 small fires $(<500$ ha) in 1974-2007; Santamaría 2015]. From 1978 to 2014, the number of fires that occurred in the area ranged from 1 to 4 (four fire recurrences identified from visual interpretation of 75 Landsat images and validation with official fire reports; Fernández-García et al. 2018). In 1998 (13-14 September, $3670 \mathrm{ha}$ ) and 2012 (19-21 August, 11,891 ha) two large high-severity wildfires burned the area (Quintano et al. 2015, 2017) resulting in undermined pine seedling recruitment and altered plant species composition at the initial stages of succession (Taboada et al. 2017): obligateseeder species dominated in areas burned by a single large fire event, whereas resprouter species dominated after repeated fires. Although $P$. pinaster forests in the study area are highly adapted to intense crown fires with more than $95 \%$ of the trees bearing serotinous cones (Tapias et al. 2004), the current fire return intervals (less than 10-15 years) hinder pine reproductive maturity and favour high-flammability shrublands, as in many areas of the western Mediterranean basin (Baeza et al. 2007; Fernandes and Rigolot 2007; González-De Vega et al. 2016).

We purchased $P$. pinaster seeds from the Forest Germplasm Bank of the National Centre of Forest Genetic Resources (Spanish Ministry of Agriculture, Food and Environment). The mature cones from which seeds were obtained had been harvested in November 2015-May 2016 from preestablished stands (1779 ha) within the study area. These established stands are as long-lasting sources from which seeds are collected by the administration for different purposes like research studies, conservation and management activities (see further details in Calvo et al. 2016). We collected P. tridentatum and H. lasianthum seeds at the study area during summer 2016. After purchase or collection, we kept the seeds in open paper bags, which allowed ventilation, at $10-15^{\circ} \mathrm{C}$ in a dry place until they were used.

\section{Thermal shock and nitrogen addition treatments}

In November 2016, a total of 1200 seeds (i.e. 48 groups of 25 seeds) from each study species were 
subjected to six combinations of temperature [control ('C'), $60{ }^{\circ} \mathrm{C}$ for $5 \mathrm{~min}$ ('MS') and $120^{\circ} \mathrm{C}$ for 5 min ('HS')] and $\mathrm{N}$ addition [without (' $\mathrm{N}-$ ') and with $\mathrm{N}\left({ }^{\prime} \mathrm{N}+\right.$ ') ] treatments (i.e. eight replicates or groups of 25 seeds per species and treatment combination).

The temperatures and exposure time were selected based on previous studies (Trabaud and Casal 1989) and on the temperatures measured with thermocouples at $1 \mathrm{~cm}$ depth during a prescribed burning (Valbuena 1995), to simulate heat exposure reached during a moderate-(MS; $60{ }^{\circ} \mathrm{C}$ for $5 \mathrm{~min}$ ) and a high-severity (HS; $120^{\circ} \mathrm{C}$ for $5 \mathrm{~min}$ ) wildfire. We submitted the seeds to the thermal shocks simultaneously, in pre-heated ceramic capsules using a dry air oven. Just after that, each group of 25 seeds per thermal treatment and species was sown in a Petri dish $(8.5 \mathrm{~cm}$ diameter, $63.61 \mathrm{~cm}^{2} ; 144$ dishes in total) on four sheets of filter paper saturated with demineralised water to prevent desiccation.

Subsequently, we added $0.034 \mathrm{~g}$ of solid granules of ammonium nitrate (i.e. $4.17 \mathrm{~g} \mathrm{~N} \mathrm{~m}^{-2}$ ) to half of the germination dishes (i.e. to a total of 24 dishes per species, and 8 dishes per thermal treatment and species), equivalent to three times the current estimate of airborne $\mathrm{N}$ deposition in the study area (European Monitoring and Evaluation Programme 2016) and to the highest predicted N input by 2050 for southern Europe (Galloway et al. 2004). The addition of $N$ to the Petri dishes did not modify $\mathrm{pH}$ values remarkably (all values ranged between 6.90 and 7). Solid granules release ammonium and nitrate slowly over the soil surface, and have been used in prior experiments assessing the ecosystem responses to airborne $\mathrm{N}$ deposition (e.g. Calvo-Fernández et al. 2018; Taboada et al. 2018).

We placed the dishes in a controlled environment cabinet at $20 \pm 1{ }^{\circ} \mathrm{C}$ with photoperiods of $15-\mathrm{h}$ light/9-h dark using a fluorescent cold light source. We watered the dishes two times per week, and inspected them weekly to determine the rate and time of seed germination. The selected temperature of $20^{\circ} \mathrm{C}$ is equivalent to that used in previous germination experiments (Trabaud and Oustric 1989). According to Côme (1970), germination was attained when the radicle could be seen with the naked eye. In agreement with the method proposed by Martínez-Sánchez et al. (1995), the experiment ended after nearly 10 days without germination. After application of the thermal and $\mathrm{N}$ fertilisation treatments, we calculated (i) the percentage of seed germination, and (2) the average seed germination time.

We used the following formula by Côme (1970) to calculate the average germination time (tm):

$$
t m=\frac{N_{1} T_{1}+N_{2} \ldots+N_{n} T_{n}}{N_{1}+N_{2} \ldots+N_{n}}
$$

where $N_{1}$ is the number of seeds that have germinated during time $T_{1}, N_{2}$ is the number of seeds that have germinated between time $T_{1}$ and time $T_{2}$ and so on.

\section{Data analysis}

Separately for each species, we fit a generalised linear model (GLM) and a linear model (LM) to test the effects of the thermal shock and $\mathrm{N}$ fertilisation treatments on the rate and time of seed germination, respectively. The response variable in the GLM was the percentage of seed germination, modelled following a quasi-Poisson error distribution, using the log link function, to account for overdispersion. The response variable in the LM was the average germination time in weeks, modelled assuming a Gaussian error distribution, using the identity link function. The predictor variables in both the GLM and LM were thermal shock treatment [i.e. control (C), $60{ }^{\circ} \mathrm{C}$ for $5 \mathrm{~min}(\mathrm{MS})$ and $120^{\circ} \mathrm{C}$ for $\left.5 \mathrm{~min}(\mathrm{HS})\right], \mathrm{N}$ fertilisation treatment $(\mathrm{N}-$ and $\mathrm{N}+$ ) and their 
interaction. The interaction term was always retained in the models, even when non-significant.

For each species, the GLM structure was:

Response variable (percentage of seed germination) $\sim$ thermal shock $\times \mathrm{N}$ treatment + error.

Similarly, for each species, the LM structure was:

Response variable (average germination time) $\sim$ thermal shock $\times \mathrm{N}$ treatment + error.

We obtained predicted values (mean and 95\% confidence intervals) of all the response variables in the GLM and LM (i.e. the rate of seed germination and the average germination time) for each species, thermal shock treatment and $\mathrm{N}$ fertilisation treatment, using the 'predict()' function.

All data analyses were carried out with R software, version 3.3.1 (R Core Team 2016) using the 'stats', and 'MASS' (Venables and Ripley 2002) packages.

\section{Results}

The percentages of seed germination of $P$. pinaster after the thermal shocks (moderate- and highseverity) were similar to those attained in the control treatment (Fig. 1; Table 1). However, the addition of $\mathrm{N}$ caused a statistically significant decrease $\left(\chi^{2}=9.67, P=0.002\right)$ in the rate of seed germination of this species in all thermal treatments. Similarly, there were no significant differences in the average seed germination time of $P$. pinaster among thermal treatments but seed germination time of this species was significantly negatively $(F=6.27, P=0.022)$ affected by $\mathrm{N}$ addition, i.e. the average germination time consistently increased after all thermal treatments due to $\mathrm{N}$ fertilisation (Fig. 2; Tables 2, 3).

\section{Fig. 1}

Model predicted values (mean $\pm 95 \%$ confidence intervals) of the seed germination rate $(\%)$ of $P$. pinaster, $P$. tridentatum and $H$. lasianthum after the thermal shock [control (C), $60{ }^{\circ} \mathrm{C}$ for $5 \mathrm{~min}$ (MS) and $120{ }^{\circ} \mathrm{C}$ for $\left.5 \mathrm{~min}(\mathrm{HS})\right]$ and $\mathrm{N}$ fertilisation $(\mathrm{N}-$ and $\mathrm{N}+$ ) treatments

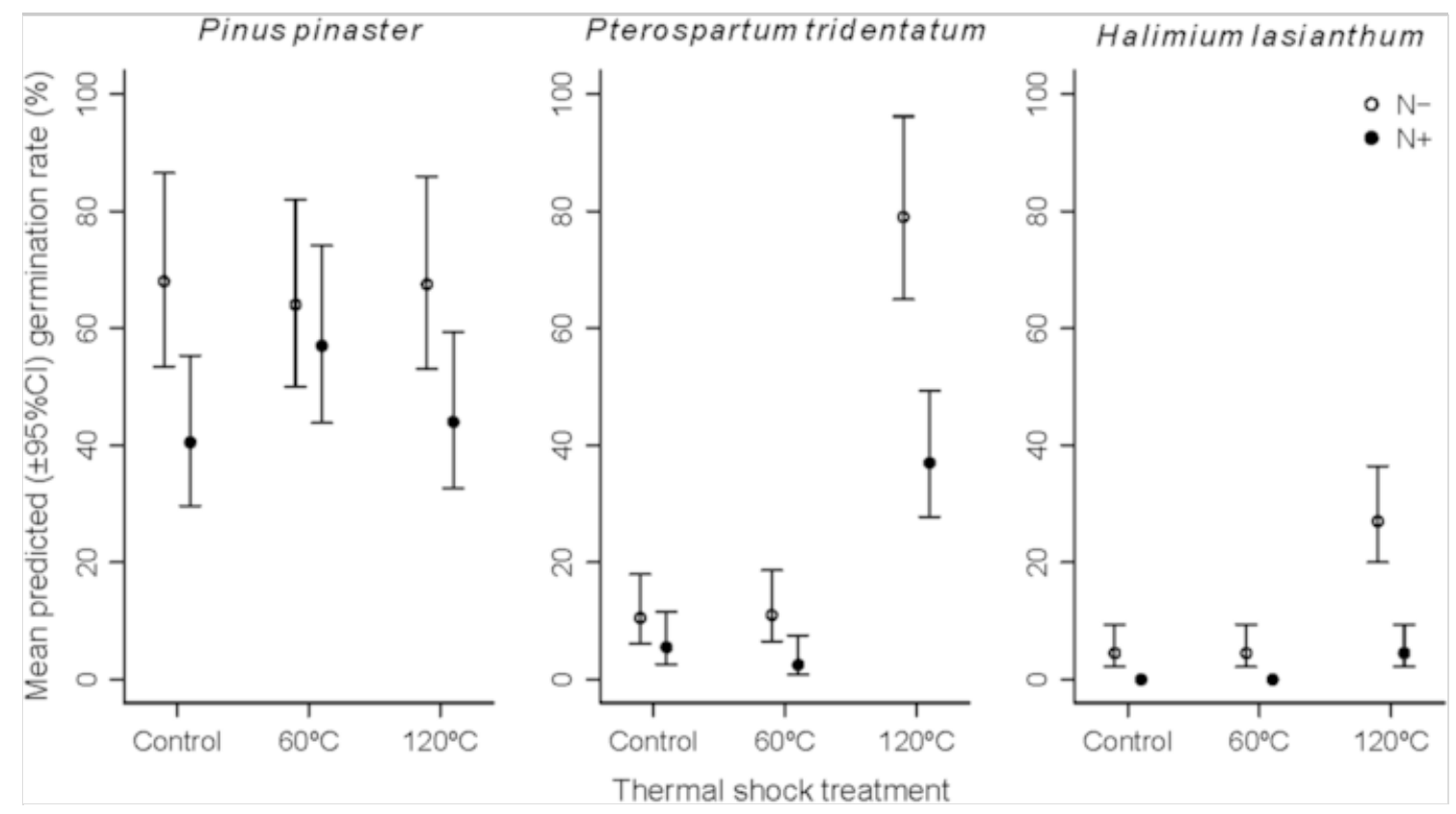




\section{Table 1}

Generalised linear model (GLM) results for the effects of the thermal shock treatments [control $(\mathrm{C}), 60{ }^{\circ} \mathrm{C}$ for $5 \mathrm{~min}(\mathrm{MS})$ and $120^{\circ} \mathrm{C}$ for $\left.\left.5 \mathrm{~min}(\mathrm{HS})\right]\right), \mathrm{N}$ fertilisation treatments $(\mathrm{N}$-and $\mathrm{N}+$ ) and their interaction on the rate

$(\%)$ of seed germination of $P$. pinaster, P. tridentatum and $H$. lasianthum

\begin{tabular}{|c|c|c|c|c|}
\hline Predictor variable & Df & Deviance & Residual deviance & $P$ value \\
\hline \multicolumn{5}{|l|}{$P$ pinaster } \\
\hline Null & & & 460.00 & \\
\hline Thermal shock treatment & 2 & 5.95 & 454.05 & 0.696 \\
\hline $\mathrm{N}$ treatment & 1 & 79.31 & 374.74 & 0.002 \\
\hline Thermal shock treatment: $\mathrm{N}$ treatment & 2 & 20.23 & 354.51 & 0.291 \\
\hline \multicolumn{5}{|l|}{ P. tridentatum } \\
\hline Null & & & 1535.74 & \\
\hline Thermal shock treatment & 2 & 1058.35 & 477.39 & $<0.001$ \\
\hline $\mathrm{N}$ treatment & 1 & 173.73 & 303.67 & $<0.001$ \\
\hline Thermal shock treatment: $\mathrm{N}$ treatment & 2 & 9.67 & 294.00 & 0.468 \\
\hline \multicolumn{5}{|l|}{ H. lasianthum } \\
\hline Null & & & 748.72 & \\
\hline Thermal shock treatment & 2 & 268.84 & 479.88 & $<0.001$ \\
\hline $\mathrm{N}$ treatment & 1 & 223.12 & 256.76 & $<0.001$ \\
\hline Thermal shock treatment: $\mathrm{N}$ treatment & 2 & 19.35 & 237.42 & 0.148 \\
\hline
\end{tabular}

Residual deviance is the amount of variation not explained by the models. Residual degrees of freedom $=$ 42. Significant $P$ values $(<0.05)$ are in bold face. $D f$ degrees of freedom

Fig. 2

Model predicted values (mean $\pm 95 \%$ confidence intervals) of the average seed germination time (weeks) of $P$. pinaster, $P$. tridentatum and $H$. lasianthum after the thermal shock [control (C), $60{ }^{\circ} \mathrm{C}$ for $5 \min (\mathrm{MS})$ and $120^{\circ} \mathrm{C}$ for $\left.5 \min (\mathrm{HS})\right]$ and $\mathrm{N}$ fertilisation $(\mathrm{N}-$ and $\mathrm{N}+$ ) treatments 

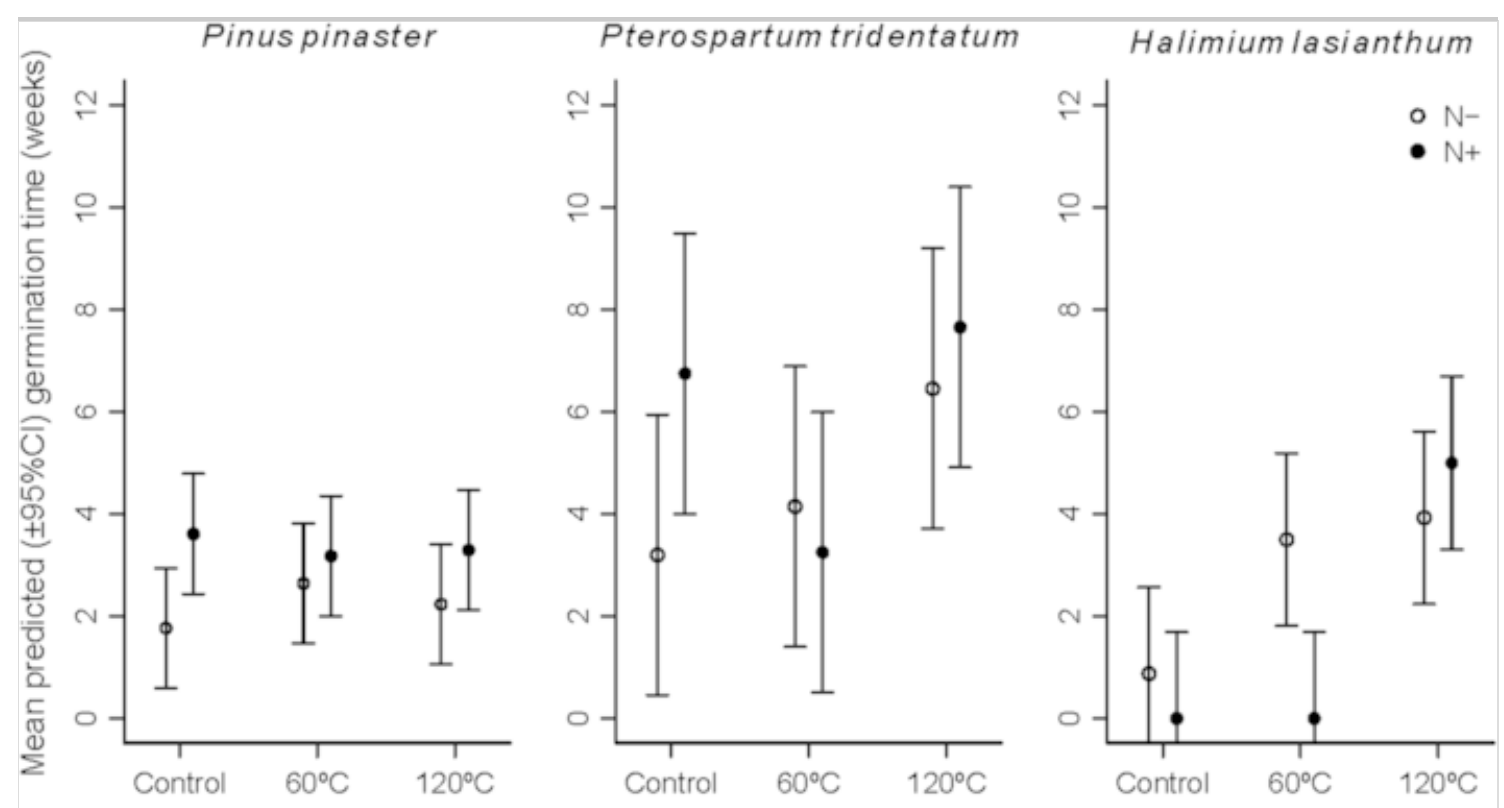

Thermal shock treatment

Table 2

Mean and standard deviation (SD) germination time (weeks) for P. pinaster, P. tridentatum and H. lasianthum

\begin{tabular}{|c|c|c|c|c|c|c|}
\hline & \multicolumn{2}{|c|}{$P$ pinaster } & \multicolumn{2}{|c|}{ P. tridentatum } & \multicolumn{2}{|c|}{ H. lasianthum } \\
\hline & Mean & SD & Mean & SD & Mean & SD \\
\hline $\mathrm{CN}-$ & 1.8 & 0.6 & 3.2 & 1.7 & 0.9 & 1.2 \\
\hline $\mathrm{CN}+$ & 3.6 & 1.5 & 6.8 & 4.5 & 0.0 & 0.0 \\
\hline $\mathrm{MSN}-$ & 2.6 & 0.5 & 4.2 & 2.7 & 3.5 & 3.5 \\
\hline $\mathrm{MSN}+$ & 3.2 & 1.0 & 3.3 & 2.2 & 0.0 & 0.0 \\
\hline $\mathrm{HSN}-$ & 2.2 & 0.5 & 6.5 & 1.0 & 3.9 & 0.7 \\
\hline HSN+ & 3.3 & 1.8 & 7.7 & 2.2 & 5.0 & 1.2 \\
\hline
\end{tabular}

Thermal shock and $\mathrm{N}$ fertilisation treatment combinations: $\mathrm{CN}-=$ control without $\mathrm{N}$ addition; $\mathrm{CN}+=$ control plus $\mathrm{N}$ addition; $\mathrm{MSN}-=$ moderate fire severity without $\mathrm{N}$ addition; $\mathrm{MSN}+=$ moderate fire severity plus $\mathrm{N}$ addition; $\mathrm{HSN}-=$ high fire severity without $\mathrm{N}$ addition and $\mathrm{HSN}+=$ high fire severity plus $\mathrm{N}$ addition

The rate of seed germination of $P$. tridentatum was significantly lower $\left(\chi^{2}=166.21, P<0.001\right)$ in the control and moderate-severity treatments than in the high-severity one (Fig. 1; Table 1). There was also a statistically significant decrease $\left(\chi^{2}=27.28, P<0.001\right)$ in the percentage of seed germination of this species after the addition of $\mathrm{N}$ in all thermal treatments. However, we found no differences in the average seed germination time of $P$. tridentatum neither among thermal treatments nor between $\mathrm{N}$ treatments (Fig. 2; Tables 2, 3).

In general, we obtained very low values of seed germination for $H$. lasianthum. Nevertheless, the percentage of seed germination of this species was significantly higher $\left(\chi^{2}=53.04, P<0.001\right)$ in the high-severity treatment than in the control and moderate-severity ones (Fig. 1; Table 1). Moreover, no seed germination was detected after the addition of $\mathrm{N}$ in the control and moderate-severity treatments; whereas the added $\mathrm{N}$ caused a significant decrease $\left(\chi^{2}=44.02, P<0.001\right)$ in the rate of seed germination in the high-severity treatment. We also found a significant interaction $(F=4.08, P$ $=0.035$ ) between thermal treatment and $\mathrm{N}$ treatment for the average seed germination time of this 
species (Fig. 2; Table 3). Compared to the control, the average germination time increased in the moderate- and high-severity treatments without $\mathrm{N}$ addition; but only in the high-severity treatment when $\mathrm{N}$ was added (Fig. 2; Tables 2, 3).

\section{Table 3}

Linear model (LM) results for the effects of the thermal shock treatments [control (C), $60{ }^{\circ} \mathrm{C}$ for $5 \mathrm{~min}$ (MS) and $120^{\circ} \mathrm{C}$ for $\left.5 \mathrm{~min}(\mathrm{HS})\right], \mathrm{N}$ fertilisation treatments $(\mathrm{N}-$ and $\mathrm{N}+$ ) and their interaction on the average time (weeks) of seed germination of $P$. pinaster, $P$. tridentatum and H. lasianthum

\begin{tabular}{|c|c|c|c|c|}
\hline Predictor variable & Df & Sum of squares & $F$ value & $P$ value \\
\hline \multicolumn{5}{|l|}{ P. pinaster } \\
\hline Thermal shock treatment & 2 & 0.205 & 0.08 & 0.922 \\
\hline $\mathrm{N}$ treatment & 1 & 7.866 & 6.27 & 0.022 \\
\hline Thermal shock treatment:N treatment & 2 & 1.738 & 0.69 & 0.513 \\
\hline Residuals & 18 & 22.597 & & \\
\hline \multicolumn{5}{|l|}{ P. tridentatum } \\
\hline Thermal shock treatment & 2 & 45.986 & 3.37 & 0.057 \\
\hline $\mathrm{N}$ treatment & 1 & 9.920 & 1.45 & 0.244 \\
\hline Thermal shock treatment: $\mathrm{N}$ treatment & 2 & 19.779 & 1.45 & 0.261 \\
\hline Residuals & 18 & 122.843 & & \\
\hline \multicolumn{5}{|l|}{ H. lasianthum } \\
\hline Thermal shock treatment & 2 & 67.46 & 13.07 & $<0.001$ \\
\hline $\mathrm{N}$ treatment & 1 & 7.27 & 2.82 & 0.111 \\
\hline Thermal shock treatment: $\mathrm{N}$ treatment & 2 & 21.06 & 4.08 & 0.035 \\
\hline Residuals & 18 & 46.47 & & \\
\hline \multicolumn{5}{|c|}{ Significant $P$ values $(<0.05)$ are in bold face } \\
\hline \multicolumn{5}{|l|}{$D f$ degrees of freedom } \\
\hline
\end{tabular}

\section{Discussion}

Under laboratory conditions, the germinative response to the thermal treatments of the three woody species tested was only partially as expected in relation to their post-fire regeneration strategies. Firstly, the rate and average time of seed germination of $P$. pinaster, an obligate-seeder species, showed no significant differences when submitted to the two heat shocks simulating a moderate- $\left(60{ }^{\circ} \mathrm{C}\right.$ for $\left.5 \mathrm{~min}\right)$ and a high-severity $\left(120^{\circ} \mathrm{C}\right.$ for $\left.5 \mathrm{~min}\right)$ wildfire and the control treatment, in agreement with our predictions and with earlier studies (e.g. Martínez-Sánchez et al. 1995; Reyes and Casal 2008; Torres et al. 2006).

In particular, our laboratory results are consistent with previous findings indicating that seed germination of P. pinaster is not heat-stimulated (Álvarez et al. 2005, 2007; Escudero et al. 1999; Martínez-Sánchez et al. 1995; Reyes and Casal 2001) and that seeds tolerate temperatures lower than $130{ }^{\circ} \mathrm{C}$ and short exposure times (Fernandes and Rigolot 2007, references therein). Our studied population exhibits high levels of serotiny (i.e. high percentage of trees bearing serotinous cones) evolved under frequent crown fires (Tapias et al. 2004) and low seed weights (Calvo et al. 2016) resulting in comparatively greater seed sensitiveness to high temperatures and lower seed resistance 
to fire than heavier seeds (Álvarez et al. 2007; Escudero et al. 2000; Reyes and Casal 2001). Yet, it has been amply proven that serotinous cones: (i) ensure seed viability during a high-severity fire (Alexander and Cruz 2012; Reyes and Casal 2002); (ii) promote seed resistance (Moya et al. 2013; Salvatore et al. 2010); (iii) guarantee seed mechanical and thermal protection (Fernandes and Rigolot 2007; Moya et al. 2008) and (iv) produce the massive discharge of seeds several days after a wildfire (De las Heras et al. 2012), delaying germination until optimal temperatures are achieved at the surface level (Hernández-Serrano et al. 2013; Saracino et al. 1997). This advantageous fireadaptive strategy of the studied population with seeds retained predominantly inside serotinous cones, therefore, ensures high levels of post-fire seed germination and sufficient seedling recruitment to obtain adequate natural tree regeneration after a single fire event (Calvo et al. 2008; see also Fernández et al. 2008; Gil et al. 2009; Rodríguez-García et al. 2010).

Secondly, the rates of germination of P. tridentatum and H. lasianthum were enhanced only when seeds were exposed to the high fire-severity treatment (i.e. heated seeds had greater germination than untreated ones). Meanwhile we found no differences in the average time of seed germination of P. tridentatum between the two heat shocks and the control treatment, but significantly greater germination time for $\mathrm{H}$. lasianthum after exposure to both the moderate- and high-severity thermal shocks. Contrary to our expectations and other findings (Rivas et al. 2006; Valbuena et al. 2002; Vasques et al. 2012), P. tridentatum, a facultative-seeder species with high-resprouting ability, had heat-stimulated germination rates just after submission of the seeds to the highest temperatures $\left(120^{\circ} \mathrm{C}\right.$ for $\left.5 \mathrm{~min}\right)$ under laboratory conditions, but equal average germination times. This may indicate that the light thermal shock $\left(60^{\circ} \mathrm{C}\right.$ for $\left.5 \mathrm{~min}\right)$ applied to simulate a moderate-severity fire was insufficient to promote significantly greater percentages and faster times of seed germination of this species consistent with Valbuena and Vera (2002).

In the case of $H$. lasianthum, a facultative-seeder species with low-resprouting ability, the greater rates of seed germination in response to the high fire-severity treatment agreed with previous results on the species (Herranz et al. 1999; Núñez et al. 2003; Trabaud and Oustric 1989; Valbuena et al. 1992). Whereas the slower germination times of the heated seeds compared to the untreated ones possibly revealed a delay in the start of germination after the thermal treatments (Rivas 2016). All in all, our laboratory-based findings only partially agree with prior laboratory heat experiments from the Mediterranean basin demonstrating that, in general, non-resprouter species exhibit higher probabilities of fire-stimulated germination and greater capacity to increase their populations after fire than resprouter species (Paula and Pausas 2008).

As predicted, the rate of seed germination of the three species studied was reduced by the addition of $\mathrm{N}$ in the unheated treatment as well as after application of the two heat shocks simulating a moderate- and a high-severity wildfire under laboratory conditions. Correspondingly, we found either no effect (in case of $P$. tridentatum) or a negative effect of $\mathrm{N}$ addition on the average time of seed germination (i.e. greater average germination times) after all thermal treatments (in case of $P$. pinaster) or just after the high-severity one (in case of $H$. lasianthum). Under the current context of increased airborne N deposition (García-Gómez et al. 2014), these results might indicate that the combination of high temperatures during fire and improved $\mathrm{N}$ availability may hinder the post-fire germinative response of a number of woody species typical from Mediterranean fire-prone ecosystems like the ones tested in our study. This may, in turn, have an unprecedented effect on plant competitive interactions and community composition following fire (see Taboada et al. 2017; Vourlitis and Pasquini 2009). Nonetheless, as our results were obtained under the controlled conditions from a laboratory experiment, they should be supported by further field-based research on the key environmental drivers of post-fire seed germination of woody species in fire-prone ecosystems under elevated $\mathrm{N}$ availability. 
Generally, the regrowth of Mediterranean pine forests after a wildfire is attained by direct regeneration of the preceding plant community, owing to the activation of resprouter species and to fire-stimulated seed germination (Calvo et al. 2012; De las Heras et al. 2012; Pausas et al. 2008). Fast-growing resprouter species are well adapted to frequent fire (Calvo et al. 2012; Pausas and Vallejo 1999); meanwhile obligate-seeder species are benefited by high-severity fires (Pausas and Keeley 2014) and high water limitation (Moya et al. 2015). As discussed above, non-resprouter species are thus highly tolerant to heat exposure and have higher potential than resprouter species to persist and even to increase their populations (i.e. owing to heat-stimulated germination) after extremely intense wildfires (Paula and Pausas 2008). Therefore, unless fires occur at a return interval shorter than the minimum required time for obligate-seeder species to reach reproductive maturity (e.g. less than 10-15 years in case of P. pinaster; Fernandes and Rigolot 2007; Tapias et al. 2001), they usually achieve high rates of seed germination and seedling emergence following fire (e.g.. Hernández-Serrano et al. 2013).

In the studied maritime pine forests adapted to dry environments and low nutrient availability (Marcos et al. 2018), the increase in soil fertility immediately after fire (Calvo et al. 2008) together with the improved post-burn environmental conditions (i.e. high availability of space and low seed predation risk; Hernández-Serrano et al. 2013) most likely result in greater competition for light, water and nutrients between gradually-recruited seedlings and fast-growing resprouter species (Calvo et al. 2013; Taboada et al. 2017). Such fire-induced changes in plant competitive interactions may overcome the potential effects of enhanced airborne $\mathrm{N}$ availability on post-fire seed germination, as the newly emerged seedlings and the new shoots produced by resprouter species may rapidly cause the depletion of nutrients in the upper soil layer. Meanwhile obligate-seeder species usually allocate nutrient resources to growth and rapid reproductive maturity (Bell 2001; Rodríguez-García and Bravo 2013), resprouter species devote them to below-ground storage structures to ensure survival after the next fire (Knox and Clarke 2005, and references therein). This might therefore imply that facultative-seeder species with high-resprouting abilities like $P$. tridentatum would be benefited at fertile sites with elevated $\mathrm{N}$ loading, making them better competitors than obligate seeders after frequent fires at short return intervals (Clarke et al. 2005; Knox and Clarke 2005; Reyes et al. 2009).

Moreover, the magnitude and direction of the effects of high $\mathrm{N}$ inputs on the post-fire germination of Mediterranean plant species may vary along moisture gradients (Bell et al. 1999; see also Li et al. 2011) or depend on the species' light tolerance (Bell et al. 1999; Luna and Moreno 2009). However, the underlying mechanisms determining the role of elevated $\mathrm{N}$ availability on seed germination after fire are still unclear. For instance, as suggested by recent studies, enhanced airborne $\mathrm{N}$ loading could influence seed production and early seedling growth differently, either depending on the availability of soil phosphorous (P) (Zhang et al. 2013) related to fire severity (Fernández-García et al. 2019a, b), or even mediated by an indirect effect of improved $\mathrm{N}$ loads on the maternal environment (Li et al. 2011).

Finally, prior research has determined increased $\mathrm{N}$ availability could have less of an effect on postfire seed germination in Mediterranean fire-prone environments than other fire-related germination cues such as smoke and charred wood (Pérez-Fernández and Rodríguez-Echeverría 2003, references therein). What is more, under real-world scenarios, post-fire abiotic conditions [e.g. absence of vegetation cover, increased soil temperature fluctuations; Jaganathan (2015)] could also interact with greater $\mathrm{N}$ loads caused by atmospheric pollution. Thus, further work is needed to disentangle the complex relations among the myriad of factors potentially affecting the post-fire germinative response of coexisting Mediterranean woody species at fire-prone ecosystems under the current 
context of elevated airborne $\mathrm{N}$ inputs.

\section{Publisher's Note}

Springer Nature remains neutral with regard to jurisdictional claims in published maps and institutional affiliations.

\section{Acknowledgements}

We thank the Environmental Department of the Regional Government of Castilla y León for the information provided.

\section{Funding}

This work was supported by the Spanish Ministry of Economy and Competitiveness, and the European Regional Development Fund (GESFIRE Project, AGL2013-48189-C2-1-R; FIRESEVES Project, AGL2017-86075-C2-1-R); and the Regional Government of Castilla and León (FIRECYL Project, LE033U14; SEFIRECYL Project, LE001P17).

\section{References}

Alexander ME, Cruz MG (2012) Modelling the effects of surface and crown fire behaviour on serotinous cone opening in jack pine and lodgepole pine forests. Int J Wildland Fire 21:709-721. https://doi.org/10.1071/WF11153

Álvarez R, Valbuena L, Calvo L (2005) Influence of tree age on seed germination response to environmental factors and inhibitory substances in Pinus pinaster. Int J Wildland Fire 14:277-284. https://doi.org/10.1071/WF04066

Álvarez R, Valbuena L, Calvo L (2007) Effect of high temperatures on seed germination and seedling survival in three pine species (Pinus pinaster, P. sylvestris and P. nigra). Int J Wildland Fire 16:63-70. https://doi.org/10.1071/WF06001

Baeza MJ, Valdecantos A, Alloza JA, Vallejo VR (2007) Human disturbance and environmental factors as drivers of long-term post-fire regeneration patterns in Mediterranean forests. J Veg Sci 18:243-252. https://doi.org/10.1111/j.1654-1103.2007.tb02535.x

Baskin CC, Baskin JM (2001) Seeds, ecology, biogeography, and evolution of dormancy and germination. Academic Press, New York

Bell DT (2001) Ecological response syndromes in the Flora of southwestern western Australia: fire resprouters versus reseeders. Bot Rev 67:417-440

Bell DT, King LA, Plummer JA (1999) Ecophysiological effects of light quality and nitrate on seed germination in species from Western Australia. Aust J Ecol 24:2-10. https://doi.org/10.1046 j.1442-9993.1999.00940.x

Bobbink R, Hicks K, Galloway J, Spranger T, Alkemade R, Ashmore M, Bustamante M, Cinderby S, Davidson E, Dentener F, Emmett B, Erisman J-W, Fenn M, Gilliam F, Nordin A, Pardo L, De Vries W (2010) Global assessment of nitrogen deposition effects on terrestrial plant diversity: a synthesis. Ecol Appl 20:30-59. https://doi.org/10.1890/08-1140.1

Britton AJ, Fisher JM (2007) Interactive effects of nitrogen deposition, fire and grazing on 
diversity and composition of low-alpine prostrate Calluna vulgaris heathland. J Appl Ecol 44:125-135. https://doi.org/10.1111/j.1365-2664.2006.01251.x

Calvo L, Baeza J, Marcos E, Santana V, Papanastasis VP (2012) Post-fire management of shrublands. In: Moreira F, Arianoutsou M, Corona P, De las Heras J (eds), Post-fire management and restoration of southern European forests, managing forest ecosystems 24. Springer, Berlin, pp 293-319

Calvo L, Hernández V, Valbuena L, Taboada A (2016) Provenance and seed mass determine seed tolerance to high temperatures associated to forest fires in Pinus pinaster. Ann For Sci 73:381-391. https://doi.org/10.1007/s13595-015-0527-0

Calvo L, Santalla S, Valbuena L, Marcos E, Tárrega R, Luis-Calabuig E (2008) Post-fire natural regeneration of a Pinus pinaster forest in NW Spain. Plant Ecol 197:81-90. https://doi.org /10.1007/s11258-007-9362-1

Calvo L, Torres O, Valbuena L, Luis-Calabuig E (2013) Recruitment and early growth of Pinus pinaster seedlings over five years after a wildfire in NW Spain. For Syst 22:582-586. https://doi.org/10.5424/fs/2013223-04623

Calvo-Fernández J, Taboada A, Fichtner A, Härdtle W, Calvo L, Marcos E (2018) Time- and agerelated effects of experimentally simulated nitrogen deposition on the functioning of montane heathland ecosystems. Sci Total Environ 613-614:149-159. https://doi.org/10.1016 /j.scitotenv.2017.08.307

Clarke PJ, Knox KJE, Wills KW, Campbell M (2005) Landscape patterns of woody plant response to crown fire: disturbance and productivity influence sprouting ability. J Ecol 93:544-555. https://doi.org/10.1111/j.1365-2745.2005.00971.x

Côme D (1970) Les obstacles à la germination. Mason, Paris

De las Heras J, Moya D, Vega JA, Daskalakou E, Vallejo R, Grigoriadis N, Tsitsoni T, Baeza J, Valdecantos A, Fernández C, Espelta J, Fernandes P (2012) Post-fire management of serotinous pine forests. In: Moreira F, Arianoutsou M, Corona P, De las Heras J (eds), Post-fire management and restoration of southern european forests, managing forest ecosystems 24 . Springer, Berlin, pp $121-150$

Doblas-Miranda E, Alonso R, Arnan X, Bermejo V, Brotons L, De las Heras J, Estiarte M, Hódar JA, Llorens P, López-Serrano FR, Lloret F, Martínez-Vilalta J, Moya D, Peñuelas J, Pino J, Rodrigo A, Roura-Pascual N, Valladares F, Vilà M, Zamora R, Retana J (2017) A review of the combination among global change factors in forests, shrublands and pastures of the Mediterranean region: beyond drought effects. Glob Planet Chang 148:42-54. https://doi.org /10.1016/j.gloplacha.2016.11.012

Escudero A, Núñez Y, Pérez-García F (2000) Is fire a selective force of seed size in pine species? Acta Oecol 21:245-256. https://doi.org/10.1016/S1146-609X(00)01083-3

Escudero A, Sanz MV, Pita JM, Pérez-García F (1999) Probability of germination after heat treatment of native Spanish pines. Ann For Sci 56:511-520. https://doi.org/10.1051 /forest: 19990608 
European Monitoring and Evaluation Programme (EMEP) (2016) Gridded emissions in Google Earth. https://www.ceip.at/ms/ceip_home1/ceip_home/webdab_emepdatabase/gridded_data/. Accessed November 2016

Fernandes PM, Rigolot E (2007) The fire ecology and management of maritime pine (Pinus pinaster Ait.). For Ecol Manag 241:1-13. https://doi.org/10.1016/j.foreco.2007.01.010

Fernández C, Vega JA, Fonturbel T, Jiménez E, Pérez-Gorostiaga P (2008) Effects of wildfire, salvage logging and slash manipulation on Pinus pinaster Ait. recruitment in Orense (NW Spain). For Ecol Manag 255:1294-1304. https://doi.org/10.1016/j.foreco.2007.10.034

Fernández-García V, Marcos E, Fernández-Guisuraga JM, Taboada A, Suárez-Seoane S, Calvo L (2019a) Impact of burn severity on soil properties in a Pinus pinaster ecosystem immediately after fire. Int J Wildland Fire 28:354-364. https://doi.org/10.1071/WF18103

Fernández-García V, Miesel J, Baeza MJ, Marcos E, Calvo L (2019b) Wildfire effects on soil properties in fire-prone pine ecosystems: indicators of burn severity legacy over the medium term after fire. Appl Soil Ecol 135:147-156. https://doi.org/10.1016/j.apsoil.2018.12.002

Fernández-García V, Quintano C, Taboada A, Marcos E, Calvo L, Fernández-Manso A (2018) Remote sensing applied to the study of fire regime attributes and their influence on post-fire greenness recovery in pine ecosystems. Remote Sens 10:733. https://doi.org/10.3390/rs10050733

Galloway JN, Dentener FJ, Capone DG, Boyer EW, Howarth RW, Seitzinger SP, Asner GP, Cleveland CC, Green PA, Holland EA, Karl DM, Michaels AF, Porter JH, Townsend AR, Vörösmarty CJ (2004) Nitrogen cycles: past, present, and future. Biogeochemistry 70:312-318. https://doi.org/10.1007/s10533-004-0370-0

García-Gómez H, Garrido JL, Vivanco MG, Lassaletta L, Rábago I, Ávila A, Tsyro S, Sánchez G, González Ortiz A, González-Fernández I, Alonso R (2014) Nitrogen deposition in Spain: modeled patterns and threatened habitats within the Natura 2000 network. Sci Total Environ 485-486:450-460. https://doi.org/10.1016/j.scitotenv.2014.03.112

Gil L, López R, García-Mateos Á, González-Doncel I (2009) Seed provenance and fire-related reproductive traits of Pinus pinaster in central Spain. Int J Wildland Fire 18:1003-1009. https://doi.org/10.1071/WF08101

González-DeVega S, De las Heras J, Moya D (2016) Resilience of Mediterranean terrestrial ecosystems and fire severity in semiarid areas: responses of Aleppo pine forests in the short, mid and long term. Sci Total Environ 573:1171-1177. https://doi.org/10.1016/j.scitotenv.2016.03.115

Green ER, Ellis RJ, Gadsdon SRM, Milcu A, Power SA (2013) How does N deposition affect belowground heathland recovery following wildfire? Soil Biol Biochem 57:775-783. https://doi.org/10.1016/j.soilbio.2012.08.025

Henig-Sever N, Eshel A, Ne'eman G, (2000) Regulation of the germination of Aleppo pine (Pinus halepensis) by nitrate, ammonium, and gibberellin, and its role in post-fire forest regeneration. Physiol Plant 108:390-397. https://doi.org/10.1034

/j.1399-3054.2000.t01-1-100408.x 
Hernández-Serrano A, Verdú M, González-Martínez SC, Pausas JG (2013) Fire structures pine serotiny at different scales. Am J Bot 100:2349-2356. https://doi.org/10.3732/ajb.1300182

Herranz JM, Ferrandis P, Martínez-Sánchez JJ (1999) Influence of heat on seed germination of nine woody Cistaceae species. Int J Wildland Fire 9:173-182. https://doi.org/10.1071/WF00014

Jaganathan GK (2015) Are wildfires an adapted ecological cue breaking physical dormancy in the Mediterranean basin? Seed Sci Res 25(2):120-126. https://doi.org/10.1017 /S0960258514000439

Jones L, Provins A, Holland M, Mills G, Hayes F, Emmett B, Hall J, Sheppard L, Smith R, Sutton M, Hicks K, Ashmore M, Haines-Young R, Harper-Simmonds L (2014) A review and application of the evidence for nitrogen impacts on ecosystem services. Ecosyst Serv 7:76-88. https://doi.org/10.1016/j.ecoser.2013.09.001

Keeley JE (2009) Fire intensity, fire severity and burn severity: a brief review and suggested usage. Int J Wildland Fire 18:116-126. https://doi.org/10.1071/WF07049

Keeley JE, Pausas JG (2018) Evolution of 'smoke' induced seed germination in pyroendemic plants. S Afr J Bot 115:251-255. https://doi.org/10.1016/j.sajb.2016.07.012

Key CH, Benson NC (2006) Landscape assessment (LA) sampling and analysis methods, USDA Forest Service general technical report, RMRS-GTR-164-CD

Knox KJE, Clarke PJ (2005) Nutrient availability induces contrasting allocation and starch formation in resprouting and obligate seeding shrubs. Funct Ecol 19:690-698. https://doi.org $/ 10.1111 / \mathrm{j} .1365-2435.2005 .01006 . x$

Li Y, Yang H, Xia J, Zhang W, Wan S, Li L (2011) Effects of increased nitrogen deposition and precipitation on seed and seedling production of Potentilla tanacetifolia in a temperate steppe ecosystem. PLoS ONE 6(12):e28601. https://doi.org/10.1371/journal.pone.0028601

Luis-Calabuig E, Torres O, Valbuena L, Calvo L, Marcos E (2002) Impact of large fires on a community of Pinus pinaster. In: Trabaud L, Prodon R (eds) Fire and biological processes. Backhuys, Leiden, pp 1-12

Luna B, Moreno JM (2009) Light and nitrate effects on seed germination of Mediterranean plant species of several functional groups. Plant Ecol 203:123-135. https://doi.org/10.1007 /s11258-008-9517-8

Marcos E, Fernández-García V, Fernández-Manso A, Quintano C, Valbuena L, Tárrega R, LuisCalabuig E, Calvo L (2018) Evaluation of composite burn index and land Surface temperature for assessing soil burn severity in Mediterranean fire-prone pine ecosystems. Forests 9:494. https://doi.org/10.3390/f9080494

Marcos E, Villalón C, Calvo L, Luis-Calabuig E (2009) Short-term effects of experimental burning on soil nutrients in the Cantabrian heathlands. Ecol Eng 35:820-828. https://doi.org /10.1016/j.ecoleng.2008.12.011

Martínez-Sánchez JJ, Marín A, Herranz JM, Ferrandis P, De las Heras J (1995) Effects of high 
temperatures on germination of Pinus halepensis Mill. and P. pinaster Aiton subsp. pinaster seeds in southeast Spain. Vegetatio 116:69-72. https://doi.org/10.1007/BF00045279

Mayor AG, Valdecantos A, Vallejo VR, Keizer JJ, Bloem J, Baeza J, González-Pelayo O, Machado AI, de Ruiter PC (2016) Fire-induced pine woodland to shrubland transitions in Southern Europe may promote shifts in soil fertility. Sci Total Environ 573:1232-1241. https://doi.org/10.1016/j.scitotenv.2016.03.243

Moreira B, Pausas JG (2018) Shedding light through the smoke on the germination of Mediterranean Basin flora. S Afr J Bot 115:244-250. https://doi.org/10.1016/j.sajb.2016.10.008

Moreira B, Tormo J, Estrelles E, Pausas JG (2010) Disentangling the role of heat and smoke as germination cues in Mediterranean Basin flora. Ann Bot 105:627-635. https://doi.org/10.1093 /aob/mcq017

Moreira F, Viedma O, Arianoutsou M, Curt T, Koutsias N, Rigolot E, Barbati A, Corona P, Vaz P, Xanthopoulos G, Mouillot F, Bilgili E (2011) Landscape: wildfire interactions in southern Europe: implications for landscape management. J Environ Manag 92:2389-2402. https://doi.org /10.1016/j.jenvman.2011.06.028

Moya D, De las Heras J, Lopez-Serrano FR, Ferrandis R (2015) Post-fire seedling recruitment and morpho-ecophysiological responses to induced drought and salvage logging in Pinus halepensis Mill. stands. Forests 6:1858-1877. https://doi.org/10.3390/f6061858

Moya D, De las Heras J, Salvatore R, Valero E, Leone V (2013) Fire intensity and serotiny: response of germination and enzymatic activity in seeds of Pinus halepensis Mill from southern Italy. Ann For Sci 70:49-59. https://doi.org/10.1007/s13595-012-0236-x

Moya D, Saracino A, Salvatore R, Lovreglio R, De las Heras J, Leone V (2008) Anatomic basis and insulation of serotinous cones in Pinus halepensis Mill. Trees 22:511-519. https://doi.org /10.1071/BT10193

Núñez MR, Bravo F, Calvo L (2003) Predicting the probability of seed germination in Pinus sylvestris L. and four competitor shrub species after fire. Ann For Sci 60:75-81. https://doi.org /10.1051/forest:2002076

Ochoa-Hueso R, Allen EB, Branquinho C, Cruz C, Dias T, Fenn ME, Manrique E, Pérez-Corona ME, Sheppard LJ, Stock WD (2011) Nitrogen deposition effects on Mediterranean-type ecosystems: an ecological assessment. Environ Pollut 159:2265-2279. https://doi.org/10.1016 /j.envpol.2010.12.019

Ochoa-Hueso R, Bell MD, Manrique E (2014) Impacts of increased nitrogen deposition and altered precipitation regimes on soil fertility and functioning in semiarid Mediterranean shrublands. J Arid Environ 104:106-115. https://doi.org/10.1016/j.jaridenv.2014.01.020

Ochoa-Hueso R, Stevens CJ, Ortiz-Llorente MJ, Manrique E (2013) Soil chemistry and fertility alterations in response to $\mathrm{N}$ application in a semiarid Mediterranean shrubland. Sci Total Environ 452-453:78-86. https://doi.org/10.1016/j.scitotenv.2013.02.049

Paula S, Pausas JG (2008) Burning seeds: germinative response to heat treatments in relation to 
resprouting ability. J Ecol 96:543-552. https://doi.org/10.1111/j.1365-2745.2008.01359x

Pausas JG, Keeley JE (2014) Evolutionary ecology of resprouting and seeding in fire-prone ecosystems. New Phytol 204:55-65. https://doi.org/10.1111/nph.12921

Pausas JG, Llovet J, Rodrigo A, Vallejo R (2008) Are wildfires a disaster in the Mediterranean basin? A review. Int J Wildland Fire 17:713-723. https://doi.org/10.1071/WF07151

Pausas JG, Paula S (2012) Fuel shapes the fire-climate relationship: evidence from Mediterranean ecosystems. Glob Ecol Biogeogr 21:1074-1082. https://doi.org/10.1111

/j.1466-8238.2012.00769.x

Pausas JG, Vallejo VR (1999) The role of fire in European Mediterranean ecosystems. In: Chuvieco E (ed) Remote sensing of large wildfires in the European Mediterranean Basin. Springer, Berlin, pp 3-16

Pérez-Fernández MA, Rodríguez-Echeverría S (2003) Effect of smoke, charred wood, and nitrogenous compounds on seed germination of ten species from woodland in central-western Spain. J Chem Ecol 29:237-251. https://doi.org/10.1023/A:1021997118146

Quintano C, Fernández-Manso A, Calvo L, Marcos E, Valbuena L (2015) Land surface temperature as potential indicator of burn severity in forest Mediterranean ecosystems. Int J Appl Earth Obs 36:1-12. https://doi.org/10.1016/j.jag.2014.10.015

Quintano C, Fernández-Manso A, Roberts DA (2017) Burn severity mapping from Landsat MESMA fraction images and land surface temperature. Remote Sens Environ 190:83-95. https://doi.org/10.1016/j.rse.2016.12.009

R Core Team (2016) R: a language and environment for statistical computing. R Foundation for Statistical Computing, Vienna, Austria. https://www.R-project.org/

Reyes O, Casal M (2001) The influence of seed age on germinative response to the effects of fire in Pinus pinaster, P. radiata and Eucalyptus globulus. Ann For Sci 58:439-447. https://doi.org /10.1051/forest:2001137

Reyes O, Casal M (2002) Effect of high temperatures on cone opening and on the release and viability of Pinus pinaster and P. radiata seeds in NW Spain. Ann For Sci 59:327-334. https://doi.org/10.1051/forest:2001137

Reyes O, Casal M (2008) Regeneration models and plant regenerative types related to the intensity of fire in Atlantic shrubland and woodland species. J Veg Sci 19:575-583.

https://doi.org/10.3170/2008-8-18412

Reyes O, Casal M, Castro Rego F (2009) Resprouting ability of six Atlantic shrub species. Folia Geobot 44:19-29. https://doi.org/10.1007/s12224-009-9029-x

Rivas M (2016) Estrategia germinativa de especies de matorral atlántico en relación con incendios forestales. PhD thesis, University of Santiago de Compostela, Spain

Rivas M, Reyes O, Casal M (2006) Influence of heat and smoke treatments on the germination of 
six leguminous shrubby species. Int J Wildland Fire 15:73-80. https://doi.org/10.1071/WF05008

Rodríguez-García E, Bravo F (2013) Plasticity in Pinus pinaster populations of diverse origins: Comparative seedling responses to light and nitrogen availability. For Ecol Manag 307:196-205. https://doi.org/10.1016/j.foreco.2013.06.046

Salvatore R, Moya D, Pulido L, Lovreglio R, López-Serrano FR, De las Heras J, Leone V (2010) Morphological and anatomical differences in Aleppo pine seeds from serotinous and nonserotinous cones. New For 39:329-341. https://doi.org/10.1007/s11056-009-9174-3

San-Miguel-Ayanz J, Moreno JM, Camia A (2013) Analysis of large fires in European Mediterranean landscapes: lessons learned and perspectives. For Ecol Manag 294:11-22. https://doi.org/10.1016/j.foreco.2012.10.050

Santamaría JE (2015) El pino pinaster de la Sierra del Teleno. Historia, ordenación, crecimiento y producción. $\mathrm{PhD}$ thesis, University of Léon, Spain

Saracino A, Pacella R, Leone V, Borghetti M (1997) Seed dispersal and changing seed characteristics in a Pinus halepensis Mill. forest after fire. Plant Ecol 130:13-19. https://doi.org /10.1023/A:1009765129920

Serrasolses I, Vallejo VR (1999) Soil fertility after fire and clear-cutting. In: Rodà F, Retana J, Gracia CA, Bellot J (eds) Ecology of Mediterranean Evergreen Oak Forests. Ecological Studies, 137. Springer, Berlin. pp 315-328. https://doi.org/10.1007/978-3-642-58618-7_22

Southon GE, Green ER, Jones AG, Barker CG, Power SA (2012) Long-term nitrogen additions increase likelihood of climate stress and affect recovery from wildfire in a lowland heath. Glob Change Biol 18:2824-2837. https://doi.org/10.1111/j.1365-2486.2012.02732.x

Taboada A, Calvo-Fernández J, Marcos E, Calvo L (2018) Plant and vegetation functional responses to cumulative high nitrogen deposition in rear-edge heathlands. Sci Total Environ 637-638:980-990. https://doi.org/10.1016/j.scitotenv.2018.05.092

Taboada A, Tárrega R, Marcos E, Valbuena L, Suárez-Seoane S, Calvo L (2017) Fire recurrence and emergency post-fire management influence seedling recruitment and growth by altering plant interactions in fire-prone ecosystems. For Ecol Manag 402:63-75. https://doi.org/10.1016 /j.foreco.2017.07.029

Tapias R, Climent J, Pardos JA, Gil L (2004) Life histories of Mediterranean pines. Plant Ecol 171:53-68. https://doi.org/10.1023/B:VEGE.0000029383.72609.f0

Tapias R, Gil L, Fuentes-Utrilla P, Pardos JA (2001) Canopy seed banks in Mediterranean pines of south-eastern Spain: a comparison between Pinus halepensis Mill., P. pinaster Ait., P. nigra Arn. and P. pinea L. J Ecol 89:629-638. https://doi.org/10.1046/j.1365-2745.2001.00575.x

Thanos CA, Rundel PW (1995) Fire-followers in chaparral: nitrogenous compounds trigger seed germination. J Ecol 83:207-216. https://doi.org/10.2307/2261559

Torres O, Calvo L, Valbuena L (2006) Influence of high temperatures on seed germination of a special Pinus pinaster stand adapted to frequent fires. Plant Ecol 186:129-136. https://doi.org 
Trabaud L, Casal M (1989) Réponses des semences de Rosmarinus officinalis à différents traitements simulant une action de feu. Acta Oecol Oecol Appl 10:355-363

Trabaud L, Oustric J (1989) Influence du feu sur la germination des semences de quatre espèces ligneuses méditerranéennes à reproduction sexuée obligatoire. Seed Sci Technol 17:589-599

Turner MG (2010) Disturbance and landscape dynamics in a changing world. Ecology 91:2833-2849. https://doi.org/10.1890/10-0097.1

Valbuena L (1995) El banco de semillas del suelo y su papel en la recuperación de comunidades incendiadas. $\mathrm{PhD}$ thesis, University of León, Spain

Valbuena L, Luis-Calabuig E, Tárrega R (2002) Relationship between thermal shock and germination in five Mediterranean shrubs. In: Trabaud L, Prodon R (eds) Fire and biological processes. Backhuys, Leiden, pp 93-98

Valbuena L, Tárrega R, Luis E (1992) Influence of heat on seed germination of Cistus laurifolius and Cistus ladanifer. Int J Widland Fire 2:15-20. https://doi.org/10.1071/WF9920015

Valbuena L, Vera ML (2002) The effects of thermal scarification and seed storage on germination of four heathland species. Plant Ecol 161:137-144. https://doi.org/10.1023/A:1020387819222

Vasques A, Maia P, Pedro M, Santos C, Vallejo VR, Keizer JJ (2012) Germination in five shrub species of Maritime Pine understory_does seed provenance matter? Ann For Sci 69:499-507. https://doi.org/10.1007/s13595-012-0206-3

Venables WN, Ripley BD (2002) Modern applied statistics with S, 4th edn. Springer, New York

Vourlitis GL, Pasquini SC (2009) Experimental dry-season N deposition alters species composition in southern Californian mediterranean-type shrublands. Ecology 90:2183-2189. https://doi.org/10.1890/08-1121.1

Zhang Y, Zhou Z, Yang Q (2013) Nitrogen (N) deposition impacts seedling growth of Pinus massoniana via $\mathrm{N}$ : $\mathrm{P}$ ration effects and the modulation of adaptive responses to low $\mathrm{P}$ (phosphorus). PLoS ONE 8(10):e79229. https://doi.org/10.1371/journal.pone.0079229 